22. Richters J, Grulich, A, de Visser R, Smith A, Rissel C. Sex in Australia: Contraceptive practices among a representative sample of women. Aust N Z J Public Health 2003; 27(2): 210-216.

23. de Visser R, Smith A, Rissel C, Richters J, Grulich A. Sex in Australia: Experience of condom failure among a representative sample of men. Aust N Z J Public Health 2003; 27(2): 217-222.

24. de Visser R, Smith A, Rissel C, Richters J, Grulich A. Sex in Australia: Safer sex and condom use among a representative sample of adults. Aust N Z J Public Health 2003; 27(2): 223-229.

25. Grulich A, de Visser R, Smith A, Rissel C, Richters J. Sex in Australia: Knowledge about sexually transmissible infections and blood born viruses in a representative sample of adults. Aust N Z J Public Health 2003; 27(2): 230-233.

26. Grulich A, de Visser R, Smith A, Rissel C, Richters J. Sex in Australia: Sexually transmissible disease and blood borne virus history in a representative sample of adults. Aust NZJ Public Health 2003; 27(2): 234-241.
27. Grulich A, de Visser R, Smith A, Rissel C, Richters J. Sex in Australia: Injecting and sexual risk behaviour in a representative sample of adults. Aust N Z J Public Health 2003; 27(2): 242-250.

28. Smith A, Rissel C, Richters J, Grulich A, de Visser R. Sex in Australia: Reflections and recommendations for future research. Aust N Z J Public Health 2003; 27(2): 251-256.

29. Williamson M, Baker D, Jorm L. The NSW Health Survey Program. Overview and Methods, 1996-2000. NSW Public Health Bull 2001; 12(S-2).

30. Watson N, Gates G. Weighting for the Australian Survey of Health and Relationships. La Trobe University: Australian Study of Health and Relationships. Available at www.latrobe.edu.au/ashr/ASHR_weighting.pdf. Accessed 18/06/2003.

31. Wen LM, Manson A, Poulos R, Rissel C. A 2001 demographic profile of the Central Sydney Area Health Service. Camperdown, CSAHS Division of Population Health, 2003.

\title{
SEX IN AUSTRALIA: THE AUSTRALIAN STUDY OF HEALTH AND RELATIONSHIPS
}

The sexual health data for New South Wales, Central Sydney, and inner-eastern Sydney, reported in this issue of the NSW Public Health Bulletin, are part of a larger survey of sexual health behaviours and attitudes of Australians. This national survey involved telephone interviews with 19,307 people aged 16-59 years from all Australian states and territories. With a 73.1 per cent response rate, and statistical weighting of the data to reflect the location, age, and sex distribution of the 2001 Census, the sample is broadly representative of the Australian population.

\section{THE MAIN REPORT}

The primary report of the Australian Study of Health and Relationships is published as 21 articles in the Australian and New Zealand Journal of Public Health, Volume 27, Number 2, April 2003.

Each article focuses on a particular aspect of the survey or content area. The first two articles present the details of the methodology used in the survey and the rationale for this approach. The final paper considers the meaning of the overall findings and the implications for future research. Each of the remaining 18 articles presents the findings of a section of the questionnaire, with the data broken down by selected variables. Generally, these variables are age, gender, language spoken at home, sexual identity, education, region of residence, household income, and occupation, although other variables are used as appropriate. A series of further analyses are planned to explore the data in more depth and to conduct multivariate analyses.

\section{CONTENT AREAS}

The questionnaire used in the Australian Study of Health and Relationships covered broad aspects of sexual health. Articles published in the April 2003 issue of Australian and New Zealand Journal of Public Health focused on:

- attitudes towards sex;

- characteristics of regular sexual relationships;

- first experiences of vaginal intercourse and oral sex;

- sexual identity, sexual attraction, and sexual experience;

- heterosexual experience and recent heterosexual encounters;

- homosexual experience and recent homosexual encounters;

- sexual difficulties;

- preferred frequency of sex, and sexual and emotional satisfaction; 
- autoerotic, esoteric, and other sexual practices;

- commercial sex;

- sexual coercion;

- reproductive experiences;

- contraceptive experiences,

- safer sex and condom use;

- condom failure;

- history of and knowledge about sexually transmitted infections and blood-borne viruses;

- injecting and sexual risk behaviour.

The Australian Study of Health and Relationships is the largest and most comprehensive survey of sexuality ever undertaken in this country. It will provide important information to guide policy and practice for years to come.

\section{HOWTO GET A COPY}

Copies of the full report are available from the Australian Research Centre in Sex, Health and Society at the cost of A \$30. Cheques payable to 'ARCSHS' should be sent to Sex in Australia, Australian Research Centre in Sex, Health and Society, La Trobe University, Level 1, 215 Franklin Street, Melbourne VIC 3000. Alternately, requests can be made by email at arcshs@latrobe.com.au or by visiting the website www.latrobe.edu.au/arcshs.

\section{CONTINUOUS NSW HEALTH SURVEY: QUARTERLY REPORT ON HEALTH STATUS, HEALTH BEHAVIOURS, AND RISK FACTORS}

Lara Harvey, Andrew Hayen, and Margo Eyeson-Annan Centre for Epidemiology and Research NSW Department of Health

This is the first of a series of quarterly reports on the surveillance of the health status, health behaviours, and risk factors of the people of NSW, which will be produced from the Continuous NSW Health Survey. Ten indicators have been selected for inclusion in the report. These have been chosen either because they are of ongoing interest or because seasonal variation is possible (Figure 1). The Continuous NSW Health Survey is conducted by the Centre for Epidemiology and Research, through the Department of Health's Computer Assisted Telephone Interviewing (CATI) facility. The data reported in this report are based on the respondents described in Table 1. Although prevalence estimates are only shown in the graphs, 95 per cent confidence intervals have been calculated and these are available on request from the NSW Health Survey Program.

\section{SELF-RATED HEALTH}

Self-rated health is believed to principally reflect physical problems and, to a lesser extent, health behaviours and mental health problems. Longitudinal studies have shown that self-rated health is a strong and independent predictor of subsequent illness and premature death. ${ }^{1}$ In 2002 , 82.0 per cent of NSW residents aged 16 years and over reported their health as being either 'excellent', 'very

\section{TABLE 1}

RESPONDENTS AGED 16 YEARS AND OVER BY COLLECTION QUARTER

\begin{tabular}{|c|c|c|c|}
\hline Quarter & Males & Females & Persons \\
\hline February-March 2002 & 386 & 609 & 995 \\
\hline April-June 2002 & 1444 & 1993 & 3437 \\
\hline July-September 2002 & 1768 & 2345 & 4113 \\
\hline October-December 2002 & 1645 & 2266 & 3911 \\
\hline
\end{tabular}

Source: NSW Health Survey Program, Centre for Epidemiology and Research, NSW Department of Health. 